\title{
The potential of epigenetic methods to provide evidence of torture
}

\author{
Paula Suárez-López, PhD*
}

\section{Key points of interest}

- Epigenetic marks are DNA modifications that affect gene activity without altering the underlying genetic information.

- Changes in epigenetic marks are associated with traumatic experiences.

- Methods that analyse epigenetic marks have the potential to contribute to the medico-legal documentation of torture. This potential should be explored.

\begin{abstract}
Introduction: The last five decades have witnessed a transition from brutal forms of physical torture to other physical and psychological methods that do not leave marks on the body. Providing evidence of these types of torture is often a challenge. Finding biological markers of torture would potentially contribute to solve this problem.

Methods: Scientific literature review.

Results: Methods to analyse certain biological marks present in the genetic material (the DNA), called epigenetic marks, have been
\end{abstract}

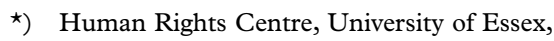
United Kingdom.

Correspondence to: paula_suarez_lopez@ hotmail.com developed in recent years. These marks can change in response to environmental factors, but these changes do not alter the genetic information contained in the DNA. Changes in epigenetic marks have been correlated with traumatic stress. Given that torture is an extreme form of trauma, this article argues that torture may also be associated with epigenetic changes.

Discussion: Epigenetic methods offer a new tool that might be useful for the medico-legal documentation of cases of torture. Given that these methods have not been used for this purpose yet, they should be tested. Whether they have potential to contribute to determine the severity of suffering, establish a severity threshold or design strategies for the rehabilitation of torture survivors is discussed. The advantages and limitations of these methods, as well as ethical implications, must be taken into account.

Keywords: severity of suffering, trauma, torture biomarkers, epigenetics, DNA methylation.

\section{Introduction}

A main element of the definition of torture in international human rights law instruments is the severity of physical or mental pain or suffering (Convention against Torture and 
Other Cruel, Inhuman or Degrading Treatment or Punishment, 1984; Rome Statute, 1997). The importance of the term "severity" resides in that, despite the fact that it has no legal definition, is a major criteria used in judicial decisions to determine whether the treatment suffered by a person amounts to torture or not. ${ }^{1}$ However, UN treaty bodies interpret that the legal distinction between torture and inhuman or degrading treatment bears little relevance, ${ }^{2}$ a view supported by research indicating that the severity of mental suffering inflicted by torture and other forms of ill-treatment is similar (Başoğlu et al., 2007). It has been proposed, therefore, that a common severity threshold should apply to both torture and cruel or inhuman treatment (Rodley \& Pollard, 2009). With the exception of certain acts generally considered torture per se due to the intensity of suffering inflicted ${ }^{3}$ (Maculan, 2015), it is necessary to evaluate whether the degree of severity reaches the common threshold to determine whether an act falls within the prohibition of torture and other ill-treatment.

Despite the fact that it is outlawed in most states, torture is still widespread in many countries (Amnesty International, 2018). Many forms of torture hardly leave any mark on the body (Greenberg, 2015; Petersen \& Morentin, 2019; Rejali, 2007; Ron, 1997). The absence

1 See e. g. ECHR. (1978). Ireland v the United Kingdom, 5310/71, $\$ 167$.

2 UN Committee Against Torture, General Comment No. 2: Implementation of Article 2 by States parties (2008), \$\$3-6; UN Human Rights Committee, General Comment No. 20: Article 7 (Prohibition of Torture, or Other Cruel, Inhuman or Degrading Treatment or Punishment) (1992), $\int \$ 3-4,8-9,14$

3 ECHR. (2003). Aktas v Turkey, 24351/94, \$319; ECHR. (1997). Aydin v Turkey, 23178/94, \$\$83, 86. of physical proof hampers prosecution of perpetrators and leaves victims with scant possibilities to get justice, reparation and redress. It is therefore of paramount importance to find ways to prove torture when it leaves no visible signs on the body. Epigenetic changes, which are modifications of the DNA that do not affect the genetic information contained in it (Gibney \& Nolan, 2010), are associated with traumatic events (reviewed by Vinkers et al., 2015; Zannas et al., 2015). Here, it is hypothesised that torture, usually an extremely traumatic experience, can also be associated with epigenetic changes.

\section{Methods}

Several interesting reviews on the epigenetics of trauma and post-traumatic stress disorder (PTSD) have already been published (Heinzelmann \& Gill, 2013; Sheerin et al., 2017; Vinkers et al., 2015; Zannas et al., 2015). This article has selected examples that illustrate how previous work on the epigenetics of trauma can inform future work on torture. To find out whether analyses of epigenetic changes in torture victims have been reported, searches included the scientific bibliographic databases PubMed (https://www.ncbi.nlm. nih.gov/pubmed) and Google Scholar (https:// scholar.google.com/), using each of the terms "torture," "refugee," "asylum seeker," "displaced person," "displaced population," and "war victim" in combination with the term "epigenetics" or in separate combinations with the following terms, which refer to different types of epigenetic marks: "DNA methylation," "histone mark," "histone modification," "histone methylation," "histone acetylation," "histone ubiquitination or ubiquitylation," "histone sumoylation," and "histone phosphorylation". 


\section{The difficulty of measuring the severity of suffering}

An absolute degree of pain or suffering that sets the threshold for torture and other illtreatment has not been established (Maculan, 2015), given that there is no objective method to measure pain or suffering and there is an enormous variation in physical pain sensitivity and mental suffering between different people (Başoğlu et al., 1997; Fillingim, 2005; Reyes, 2007). Factors related to torture itself, its physical effects and the general context in which it is inflicted also have to be taken into account (Maculan, 2015; Pérez-Sales, 2017; Reyes, 2007; Rodley \& Pollard, 2009). It is difficult to reconcile the complexity of measuring the severity of pain or suffering with the legal need for certainty in understanding where the threshold for severe pain or suffering is. There is a continuum in severity from the mildest forms of humiliation to the most atrocious forms of torture. It might seem arbitrary to set the threshold at a particular level, but at the same time it would be useful to set a loose boundary beyond which any treatment is considered impermissible. Some leeway would allow taking into account all the factors mentioned above.

\section{Torture that leaves no permanent marks}

There is a vast array of torture methods that do not leave permanent marks on the body, either because they do not produce them or because the marks disappear in a relatively short time. These techniques include positional stress, exhaustion exercises, sleep deprivation, hooding, sensory deprivation or sensory overload, exposure to cold or hot temperatures, waterboarding, several forms of beating (for example, with rubber hose or sandbags), and electrotorture, which can produce intense physical pain, mental suffering and sometimes permanent physical or psychological damage (Carinci et al., 2010; Rejali, 2007; Williams \& Amris, 2017). Although psychological torture can sometimes also cause physical pain, it does not result in visible physical marks (Reyes, 2007). Examples of psychological torture methods are humiliation, death threats, mock executions, threats that another person will be killed or tortured, witnessing torture of others, solitary confinement, violation of taboos, and forced betrayal (Carinci et al., 2010; McColl, Bhui, \& Jones, 2012; Reyes, 2007).

We tend to be more horrified by torture involving physical cruelty, but the methods mentioned above can cause a similar level of distress (Başoğlu et al., 2007; Pérez-Sales, 2017). For instance, torture survivors often describe that witnessing torture of family members, or the threat of torturing them, is at least as distressing as being tortured themselves (Başoğlu et al., 2007; Pérez-Sales, 2017). From the 1970s, countries like the United States, Israel and Spain, among many others, have moved from scarring physical torture to techniques that leave no permanent marks (Greenberg, 2015; Petersen \& Morentin, 2019; Rejali, 2007; Ron, 1997). In terms of proving the existence of a human rights violation, this absence of marks poses a considerable challenge.

\section{Psychological effects of torture}

The experience of extreme suffering that represents any type of torture has an emotional and psychological impact on the victim, which can result in mental health sequelae (Masmas et al., 2008; Rasmussen et al., 2011; Reyes, 2007; Steel et al., 2009). Survivors range from those experiencing a small impact and showing no difference in mental health relative to the general population to those suffering severe psychiatric disorders (Başoğlu et al., 1994; Kelly, 2011; Pérez-Sales, 2017). The psychological sequelae of torture depend 
on the survivor's age, gender, resilience, preparedness for torture and interpretation of meaning, in addition to social, cultural and political factors (Başoğlu et al., 1997; Reyes, 2007). The torturing environment and the combination of several torture methods also influence the psychological effects (PérezSales et al., 2016). Torturers want to cause fear, anxiety, distress and a feeling of helplessness in their victims, in order to break them psychologically. This can cause cognitive, behavioural and emotional problems (Campbell, 2007; Carinci et al., 2010; Turner \& GorstUnsworth, 1990). Some of the most common psychological effects are irritability, sleeplessness, memory and concentration impairment, re-experiencing the trauma, avoidance of anything recalling the torture events, anxiety, depression, suicidal thoughts, mistrust of others, and depersonalisation (feeling detached from one's body) (Carinci et al., 2010; Reyes, 2007; Turner \& Gorst-Unsworth, 1990).

Even if torture does not result in mental health symptoms in some survivors, it is a traumatic event. The severity of trauma depends on the emotional impact that torture has on the survivor, measured as the degree of distress and perception of loss of control, that is, the feeling of being at the mercy of others (Başoğlu et al., 2007; Reyes, 2007). The most prevalent trauma-related disorders among torture survivors are major depression and PTSD. It is not unusual for a survivor to have more than one disorder or to transition from one to another (Carinci et al., 2010; Nickerson et al., 2017; Weisleder \& Rublee, 2018). Most survivors suffer depression, which has been associated with the experience of loss resulting from torture. It can be loss of parts of the body, physical health, bodily functions, family, work or credibility (Turner \& Gorst-Unsworth, 1990).
The most frequent psychiatric disorder in torture survivors is post-traumatic stress disorder (PTSD) (Carinci et al., 2010), with considerably higher prevalence than in the general population (Başoğlu et al., 1994; Jaranson et al., 2004; Masmas et al., 2008; Van Ommeren et al., 2001). It is important to stress that not developing PTSD does not mean that the person has not been tortured (Pérez-Sales, 2017). Neither does PTSD, nor other longterm mental health sequelae, such as depression, reflect the severity of the treatment. Some people subjected to extremely harsh torture may not develop PTSD, whereas some people subjected to milder forms of torture may develop it. However, the severity of mental suffering correlates with greater likelihood of developing PTSD and depression (Başoğlu et al., 2007). Despite the fact that it is currently impossible to distinguish PTSD associated with torture from PTSD caused by other traumatic events, a PTSD diagnosis in a survivor is consistent with severe mental suffering and, together with other evidence, can be used to support torture claims (Reyes, 2007). Overall, any torture method causes traumatic stress, which often results in long-term psychological and mental health sequelae, with profound effects on the survivor's life (Carinci et al., 2010).

\section{The need for biological markers when torture leaves no physical marks}

The idea behind the transition to torture that leaves no permanent physical marks is that if there are no visible marks, the perpetrators will easily evade accountability. These torture methods leave the survivor, and the families of those who do not survive the experience, with little evidence to claim justice, reparation and redress. Torture that leaves no marks has little visual and public impact (Rejali, 2007), resulting in less pressure on states to change 
their laws, policies and practices. In addition, many stealth techniques do not require any technology at all and go undetected easily (Rejali, 2007). It is far more difficult to prevent, monitor, detect and prosecute nomarks torture than torture that causes physical injuries. The same problems exist when physical torture leaves marks but they have disappeared by the time the survivor is examined by a health professional. Furthermore, the narrative of torture survivors is often "circuitous, devious and evasive" rather than linear (Roth, 2013, p. 335). Torture, as an extremely distressing event, is particularly difficult to recount (Gorman, 2001). Survivors' testimonies can at times show inconsistencies and may not be able to provide precise details about the date, location or perpetrators. This can be the consequence, for instance, of the circumstances of torture, such as if the victim was blindfolded, of memory impairment resulting from physical or psychological damage caused by torture, or of fear of putting themselves or others at risk (McColl et al., 2012).

Psychological assessments are of paramount importance in documenting torture allegations and in evaluating the severity of suffering and the effects of torture in mental health (Campbell, 2007). However, the absence of physical signs and often witnesses, together with difficulty in providing a clear narrative of the torture events, often puts into question the credibility of torture allegations. In the last two decades, several tools to assess the consistency of torture narratives have been developed, including the guidelines of the Istanbul Protocol (2004). Credibility assessments can be the only evidence that many survivors have to support their legal cases (Pérez-Sales, 2017), but judges can refuse to accept them (Good, 2004). In addition, there can be considerable variation in the level of credibility determined by differ- ent observers, even when there is physical evidence of torture (Petersen \& Morentin, 2019). Credibility assessments, then, are relevant to support torture allegations, but often are not sufficient by themselves. Also, psychological assessments can occasionally be manipulated, especially if the expert is not independent. ${ }^{4}$

In the light of all of the above, an important challenge is to obtain additional evidence of torture, especially when there are no physical marks. Pérez-Sales (2017) points to the necessity of finding biological markers associated with psychological torture and that can discriminate, if possible, torture from other types of trauma. The idea is to find specific and objective evidence of torture and of the severity of its effects (Pérez-Sales, 2017)). Given that torture affects brain functioning, methods that analyse brain structure or neural activity have the potential to provide relevant information. Research using neuroimaging techniques has shown that the volume of the hippocampus is reduced in people with PTSD in comparison with traumatised people without PTSD and non-traumatised controls (Karl et al., 2006; Kolassa \& Elbert, 2007). However, these findings have to be interpreted with caution, given that differences in hippocampal volume may result from genetic risk factors for PTSD (Gilbertson et al., 2002; Zhang et al., 2014). Analyses of neural activity suggest that individuals with PTSD, including torture survivors, show specific activation patterns in response to disturbing stimuli (Adenauer et al., 2010; Catani et al., 2009). These results are promising, but neural activity patterns are not always reproducible and are sometimes difficult to interpret (Nash et al., 2014). Moreover, neuroimaging

4 See, for example, Inter-American Commission on Human Rights. (2018). Olivier Acuña Barba v Mexico, Updated petition, No. P463-05/Case 13.432 . 
procedures are expensive and require specialised equipment to which, depending on the context, torture survivors may not have access.

The levels of cortisol, a steroid hormone involved in stress responses, are altered in people who have suffered trauma (Steudte-Schmiedgen et al., 2016). Although a study of cortisol levels included torture survivors, it was not designed to test a correlation of cortisol levels with torture (Gola et al., 2012). Therefore, changes in cortisol levels are associated with trauma, but an association with torture has not been established yet. Altogether, it can be concluded that no specific biological markers of torture have been found so far. It is, therefore, of paramount importance to find new ways to document cases of torture when there are no visible signs on the body. In the next section, the potential of stateof-the-art molecular biology techniques, in particular epigenetic methods, to provide evidence of torture is analysed.

\section{The potential of epigenetic marks as biological markers of torture}

\section{What are epigenetic marks?}

Our genetic information is encoded in our DNA, which can be understood as containing a language (the genetic code). The set of genes of an organism (the genome) can be understood as a handbook of life written in this language. Your DNA contains the instructions to make you and not any other person or any other living being. But you are not only what your genes determine; you are the result of the interaction between your genes and the environment, between your genes and your experiences (Tiffon, 2018). We can understand a gene as an instruction. For example, we have a gene with the instruction to make insulin, which is involved in sugar metabolism and the control of blood sugar levels (Röder et al., 2016). A genetic change - what is called a mutation, that is, a change that affects the information contained in the gene - in the insulin gene can render insulin inactive, leading to diabetes (Nishi \& Nanjo, 2011). Instructions that are absolutely essential for life are given constantly, whereas other instructions are given at a particular moment, under particular circumstances or at particular places. For example, the insulin gene is only active in certain pancreatic cells (Röder et al., 2016). Instructions can be given in many different ways: genes can be expressed (active) or silent (inactive) and changes in gene activity can be sudden or slow and gradual, slight or massive, long-lasting or transient. Thus, gene expression can be fine-tuned in a very dynamic way.

Epigenetics refers to features of the DNA that affect gene activity without changing its genetic information. Epigenetic marks are elements that are bound to the DNA and can be added or removed readily. We can understand epigenetic marks as tags that give orders to modulate gene expression (Gibney \& Nolan, 2010). There are tags that make genes more active and tags that reduce their activity or turn them silent. The type, number and position of epigenetic marks in a gene determine gene activity. There are several types of epigenetic marks. Some of them directly bind the DNA, whereas others bind components associated with the DNA called histones (Gibney \& Nolan, 2010). The main mark directly bound to the DNA is called DNA methylation, which is a stable epigenetic mark that reduces or silences gene expression (Jaenisch \& Bird, 2003). For example, expression of the insulin gene is regulated by DNA methylation, such that this gene is expressed only in the pancreatic cells in which the gene is not methylated, allowing the gene to be active (Kuroda et al., 2009). Epigenetic change, that is, the addition or removal of epigenetic marks, is a natural 
process that contributes to the regulation of gene expression (Gibney \& Nolan, 2010). There is clear evidence that gene expression can change in response to environmental factors, such as temperature or nutrition. The environment affects gene expression in part through epigenetic changes (Cavalli \& Heard, 2019; Jaenisch \& Bird, 2003).

\section{Stress and trauma are associated with epigenetic changes}

Numerous studies have found that epigenetic changes, in particular in DNA methylation, are associated with stress and trauma. Some of these investigations have analysed methylation in the whole set of genes, whereas others have analysed methylation in specific genes that are involved in responses to stress or trauma (reviewed by Vinkers et al., 2015; Zannas et al., 2015). The main candidate genes analysed in relation to traumatic stress are those with the instructions to produce the glucocorticoid receptor and the serotonin transporter. The glucocorticoid receptor binds steroid hormones, mainly cortisol, and is involved in responses to stress and, in mice, in the regulation of anxiety, aggression and cognitive performance (de Kloet et al., 2005). The serotonin transporter is involved in the function of serotonin, a neurotransmitter, which has been related to depressive disorders (Nautiyal \& Hen, 2017). Most research on the epigenetics of trauma has been performed on patients with PTSD in order to identify genetic risk factors for this disorder (Sheerin et al., 2017; Zannas et al., 2015). Although differences in DNA methylation between patients with PTSD and trauma-exposed controls without PTSD have been detected in several genes (Sheerin et al., 2017; Zannas et al., 2015), the design of these studies does not allow concluding whether the epigenetic changes result from the trauma experienced.

A number of studies show a correlation between certain epigenetic marks in adults and childhood trauma, including early parental loss, physical and sexual abuse (reviewed by Vinkers et al., 2015). Not only does this show that traumatic stress is associated with epigenetic changes, it also suggests that these changes persist for years. In a study of DNA methylation levels in the glucocorticoid receptor gene in adults with mental disorders, higher methylation levels were found in persons that had been sexually abused during childhood compared to non-sexually abused persons (Perroud et al., 2011). Similarly, physical abuse, physical neglect, emotional abuse and emotional neglect during childhood were associated with high methylation levels in this gene. This study also found a correlation between increased severity of sexual abuse and increased DNA methylation, and between more abuses and increased methylation in the glucocorticoid receptor gene, suggesting that high levels of certain epigenetic marks might be used not only as biological markers of trauma, but also as indicators of the objective severity of the abuse.

These results, which were obtained using blood samples, extend previous work done with brain samples of suicide victims with a history of childhood abuse, which also showed higher methylation levels in the glucocorticoid receptor gene than those of non-abused suicide victims (McGowan et al., 2009). As blood samples show similar results to brain samples, it is not necessary to use brain samples for this type of research, and, therefore, it is possible to study epigenetic changes in living persons. Increased methylation of the glucocorticoid receptor gene is associated with reduced expression of this gene in the brain, which suggests that these epigenetic changes result in changes in gene activity that can affect the response to stress (McGowan et al., 2009). Research from 
a different group has found that higher methylation levels of the glucocorticoid receptor gene are associated with clinical severity in borderline personality disorder patients with a history of childhood trauma (Martín-Blanco et al., 2014). Therefore, at least two studies have found correlations between methylation of this gene and severity, although in one case severity refers to the treatment and, in the other, it refers to clinical symptoms.

Studies of epigenetic marks in other genes, including the serotonin transporter gene, have also shown an association of epigenetic changes with childhood trauma (H.-J. Kang et al., 2013; Vijayendran et al., 2012), although other studies have not found such correlation (Marzi et al., 2018; Wankerl et al., 2014). Several analyses of DNA methylation in the whole human genome have found higher or lower levels of methylation in numerous genes in individuals who had suffered childhood abuse in comparison with control individuals who had not experienced trauma (reviewed by Vinkers et al., 2015). In addition to these reports of exposure to trauma in early life, several studies have shown associations between alterations in methylation levels of several genes and war-related PTSD in veterans (Kang et al, 2019; Kim et al., 2017; Rusiecki et al., 2012; Yehuda et al., 2015), suggesting that trauma in adult life also correlates with DNA methylation changes.

In some cases, different studies have revealed epigenetic changes in different parts of the same gene. However, the methods used differ between studies and therefore the results are not directly comparable, which might explain some of the differences found (Vinkers et al., 2015). Although not all studies have found correlations between changes in DNA methylation and traumatic stress, and there is not always consistency between studies, there is increasing evidence support- ing this correlation. Two types of experiments give strong support to the idea that stress and trauma induce epigenetic changes. On the one hand, experiments in rats showed that reduced maternal care increases methylation of the glucocorticoid receptor gene in the offspring (Weaver et al., 2004). On the other hand, high methylation of genes involved in the regulation of sleep/wake cycles results from acute sleep deprivation in humans (Cedernaes et al., 2015). The field of epigenetics is young and rapidly evolving. Although many findings need further confirmation or development, it is a field with a very promising future.

\section{Can epigenetic methods be used to provide evidence of torture?}

The association of epigenetic changes with traumatic and stressful events has led to naming these changes "molecular scars" (Tsankova et al., 2006, p. 523). Given that torture is an extreme form of trauma, it is conceivable that it is also associated with this type of scars in the victim's DNA. It would be feasible, then, to test whether torture survivors show stress- or trauma-related epigenetic changes. The fact that changes in DNA methylation can be detected in adults after a history of childhood trauma (McGowan et al., 2009; Perroud et al., 2011), suggests that traumatic events may be traced in the DNA after several decades. Therefore, if such marks were associated with torture, it might be possible to detect them years after the torture event took place. Molecular scars might persist for a longer time than some physical scars and might be present in survivors of torture that leaves no other visible marks. Epigenetic methods, therefore, have the potential to provide scientific evidence of, or consistent with, torture even if years have passed and physical marks have disappeared or never existed. 
Despite this potential, systematic bibliographic searches did not retrieve any report on the use of epigenetic methods to detect associations of epigenetic changes with torture. The searches retrieved a number of articles dealing with the epigenetics of traumatised individuals, some of whom had experienced torture, but none of these articles specifically addressed potential links of epigenetic changes with torture. The present article argues that it is worth testing whether these links exist and, if this were the case, whether the changes associated with torture can be distinguished from those associated with other types of trauma.

\section{Advantages and limitations of epigenetic methods and ethical considerations}

The use of DNA analyses has meant a remarkable improvement for forensic genetics not only in criminal, but also in human rights investigations (Kirschner \& Hannibal, 1994; Williams \& Wienroth, 2017). Forensic epigenetics is an emerging area of forensics that is already being used to try to determine, using biological samples, the age of a person and to differentiate between identical twins (Vidaki \& Kayser, 2018). It would be worth testing whether this area can be extended to the documentation of torture. The idea would not be to replace other forms of evidence already available, but to provide additional proofs consistent with the torture suffered, especially when there is no other physical evidence. If epigenetic methods were useful to provide evidence of torture, they might be considered in the future for inclusion in the Istanbul Protocol.

Taking into account that different environmental factors result in epigenetic changes in different genes (Jaenisch \& Bird, 2003), it can be speculated that different types of torture might be associated with epigenetic changes in different sets of genes. Similar to DNA methyl- ation changes in genes involved in sleep/wake cycles caused by sleep deprivation (Cedernaes et al., 2015), it can be hypothesised, for instance, that positional stress might affect genes involved in muscle function, and death threats or torture threats might affect genes involved in fear responses. Perhaps, then, certain epigenetic changes might be distinctive of particular torture methods, whereas changes in genes involved in general responses to trauma would not be distinctive of torture. Other epigenetic marks, in addition to DNA methylation, might be explored. For example, changes in histone acetylation have been linked to major depression, memory impairment and cognitive problems (Penney and Tsai, 2014; Uchida et al., 2018), which are common sequelae of torture. Although we are still far from understanding the effect of trauma-associated epigenetic changes on health, physiology and behaviour, future research may shed light on this and therefore open avenues to help mitigate the effects of trauma in torture survivors, contributing to their rehabilitation.

Higher levels of DNA methylation have been associated with the severity of trauma-related clinical symptoms. It would be possible to test whether different levels of suffering correlate with higher or lower levels of epigenetic marks to try to determine the severity of torture. However, even if epigenetic methods could give a measure of the severity of suffering, it would not be easy to establish a severity threshold because there is a continuous gradation of severity from the mildest forms of degrading treatment to the cruellest forms of psychological and physical torture (Başoğlu et al., 2007). A question that needs to be answered is whether the epigenetic changes are associated with the traumatic event itself or with the mental suffering caused by the event. Traumatic stress is related to subjective severity rather than objective severity and, there- 
fore, is not directly caused by the torture event itself, but by its perceived stressfulness and uncontrollability (Başoğlu et al., 2007). In this regard, not all torture survivors experience mental disorders (Kelly, 2011). Similarly, it can be hypothesised that epigenetic alterations might not be present in every tortured person. It is not inconceivable that, in the future, the presence of certain epigenetic changes might indicate a prohibited treatment, whereas their absence would not necessarily mean that torture has not been inflicted. As the Istanbul Protocol states $(\$ 161)$, absence of evidence does not mean evidence of absence.

It is worth noting, although this will not be considered in depth here, that there is extensive literature on the intergenerational transmission of trauma effects, including the impact of parental torture on children (Bowers \& Yehuda, 2016; Daud et al., 2005; Dekel \& Goldblatt, 2008; Plant et al., 2018; Sangalang $\&$ Vang, 2016). Evidence that epigenetic marks can be inherited is also increasing (Skvortsova et al., 2018). In humans, there is controversy over whether the transmission of epigenetic marks across generations occurs through the germline or through environmental or cultural effects (Horsthemke, 2018). Even with this caveat in mind, a few studies have explored the association of epigenetic marks with the transmission of trauma and stress to the offspring, albeit with conflicting results (Ramo-Fernández et al., 2019; Yehuda et al., 2014; Yehuda et al., 2016). This field of research, identified as a priority in the context of torture (PérezSales et al, 2017), deserves further attention.

An important limitation of the epigenetic analyses of trauma performed so far, with the exception of some experiments performed in animals and sleep deprivation experiments, is that only correlations have been found. It is difficult to establish a causal relationship between trauma and epigenetic changes in human beings. Given that it is ethically inadmissible to subject people to traumatic experiences, let alone to torture, for scientific purposes, establishing whether epigenetic changes result from torture would be challenging. In addition, the task of associating epigenetic marks specifically with torture, rather than with other traumatic events in a particular survivor, may find the same problems as associating PTSD with torture. For example, in the case of refugees who have experienced torture, the process of migration very often involves traumatic events, and this makes virtually impossible to discern whether PTSD is the result of torture or other traumas (Rasmussen et al., 2011). Nevertheless, epigenetic changes might still provide evidence consistent with torture, which would be helpful when there is no other physical proof. Another limitation is that epigenetic methods, in principle, cannot determine the time when the epigenetic changes occurred. In addition, some of the methods are expensive and require specialised equipment, but DNA technologies evolve rapidly and become cheaper in a relatively short time. Also, the epigenetic changes associated with trauma are usually small and not always reproducible or statistically robust (Houtepen et al., 2018; Vinkers et al., 2015), which might limit their validity as biomarkers. It would be necessary to establish laboratory standards in order to ensure the effectiveness of the investigations and the robustness and reliability of the results.

Epigenetic marks can vary across tissues, but the type of tissue samples that can be obtained from living individuals is limited. Samples that have been used for trauma-related epigenetic analyses include saliva and buccal epithelial cells, which can be collected by non-invasive and painless methods, and blood (Vinkers et al., 2015). It is not known how the results obtained in these tissues cor- 
relate with other tissues, such as the brain, although the results obtained for the glucocorticoid receptor gene in blood seem consistent with those obtained in the brain (McGowan et al., 2009; Perroud et al., 2011). The type of samples that can be used would not be a limitation when torture results in death, as long as samples can be collected from the victim, since epigenetic changes associated with early-life trauma can be detected post-mortem (Labonté et al., 2012; McGowan et al., 2009).

The same ethical concerns as in any scientific research done with human samples have to be taken into account. All the bioethics principles, such as those established in the Declaration of Helsinki (2013) and in the Convention on Human Rights and Biomedicine (1997), must be respected. These include, for instance, avoiding all unnecessary physical and mental suffering; obtaining free and informed consent; and allowing the subjects to withdraw from the experiments or withdraw their consent when desired. It is essential to bear in mind that torture survivors can be especially vulnerable and, therefore, the highest ethical standards must be observed. Also, re-traumatisation must be avoided and the collection of samples must be done using the least invasive procedure. For example, saliva samples would be preferable to blood samples. The methods to analyse some epigenetic marks, such as DNA methylation, involve revealing at least part of the DNA sequence (the genetic information) of the subject. Torture survivors must be protected from the use against them of their genetic and epigenetic information revealed by these methods. It will also be crucial to guarantee data privacy and confidentiality of all information collected from torture survivors, including genetic and epigenetic information.

Finally, before epigenetic methods can be used to provide evidence of torture, extensive discussions with different experts, including epigenetics scientists, health professionals specialised in the assessment and treatment of torture survivors, forensic scientists, bioethicists, and legal experts must be undertaken. Also, it would be essential to take into account the perspective of torture survivors, as they would be the direct beneficiaries of the application of these scientific methods.

\section{Conclusion}

It is often difficult to prove that a person has been tortured when there are no physical marks. Finding biological markers of this extremely traumatic experience would be crucial to provide proof of torture in these cases. So far, no such markers have been found. Methods to detect epigenetic changes in the DNA offer a novel technology that may be tested for this purpose. Epigenetic changes have been associated with several types of traumatic stress. Using the DNA of torture victims, it should be possible to determine whether there are differences in epigenetic marks between them and people who have not been tortured, as well as between torture victims and people who have suffered other types of traumatic stress, that is to say, whether there are epigenetic marks that are distinctive of torture. Whether these methods can be used to determine the severity of the traumatic stress associated with torture or other forms of ill-treatment is at least a theoretical possibility. It can be concluded that epigenetic methods have the potential to provide evidence of torture and perhaps determine its severity. However, caution must be exercised to avoid overpromising. Whether this potential will be realised is not known, but given the necessity to prove torture, especially when there are no physical marks, it would be worth testing it. The interpretation of results will have to take into account the limitations of these methods. A scrupulous respect for 
the bioethical principles that regulate scientific research using human samples will also be essential.

If torture left marks in the DNA, revealing these marks would be useful for the medico-legal documentation of torture. Torturers would find much more difficult to evade accountability and potential perpetrators would be more likely to refrain from torturing. Biological markers of torture would contribute to provide justice, reparation, remedy, redress, and perhaps rehabilitation to survivors and families of victims. If epigenetic marks of torture were found, this would show that torture affects our very biological essence, the DNA carrying the genetic information that makes us human. This would lend further support to the absolute prohibition of torture and perhaps would help to refine the definition of torture on the basis of scientific evidence.

\section{Acknowledgements}

Carla Ferstman for critical comments on the manuscript, Renos Papadopoulos for discussing with me the complex psychological effects of torture, and the Editor-in-Chief and two anonymous reviewers for their help in improving the manuscript.

\section{References}

Adenauer, H., Pinösch, S., Catani, C., Gola, H., Keil, J., Kißler, J., \& Neuner, F. (2010). Early processing of threat cues in posttraumatic stress disorder-Evidence for a cortical vigilanceavoidance reaction. Biological Psychiatry, 68(5), 451-458. doi: 10.1016/j.biopsych.2010.05.015

Amnesty International. (2018). Amnesty International report 2017/18: The state of the world's human rights. London: Amnesty International.

Başoğlu, M., Livanou, M., \& Crnobarić, C. (2007). Torture vs other cruel, inhuman, and degrading treatment: Is the distinction real or apparent? Archives of General Psychiatry, 64(3), 277-285. doi: 10.1001/archpsyc.64.3.277

Başoğlu, M., Mineka, S., Paker, M., Aker, T., Livanou, M., \& Gök, Ş. (1997). Psychological preparedness for trauma as a protective factor in survivors of torture. Psychological Medicine, 27(6), 1421-1433. doi: 10.1017/s0033291797005679

Başoğlu, M., Paker, M., Paker, Ö., Özmen, E., Marks, I., Incesu, C., . . Sarimurat, N. (1994). Psychological effects of torture: A comparison of tortured with nontortured political activists in Turkey. American fournal of Psychiatry, 151, 7681. https://ajp.psychiatryonline.org/

Bowers, M. E., \& Yehuda, R. (2016). Intergenerational transmission of stress in humans. Neuropsychopharmacology, 41(1), 232244. doi: 10.1038/npp.2015.247

Campbell, T. A. (2007). Psychological assessment, diagnosis, and treatment of torture survivors: A review. Clinical Psychology Review, 27(5), 628-641. doi: 10.1016/j.cpr.2007.02.003

Carinci, A. J., Mehta, P., \& Christo, P. J. (2010). Chronic pain in torture victims. Current Pain and Headache Reports, 14(2), 73-79. doi: 10.1007/ s11916-010-0101-2

Catani, C., Adenauer, H., Keil, J., Gola, H., \& Neuner, F. (2009). Pattern of cortical activation during processing of aversive stimuli in traumatized survivors of war and torture. European Archives of Psychiatry and Clinical Neuroscience, 259(6), 340-351. doi: 10.1007/ s00406-009-0006-4

Cavalli, G., \& Heard, E. (2019). Advances in epigenetics link genetics to the environment and disease. Nature, 571(7766), 489-499. doi 10.1038/s41586-019-1411-0

Cedernaes, J., Osler, M. E., Voisin, S., Broman, J.E., Vogel, H., Dickson, S. L., . . B Benedict, C. (2015). Acute sleep loss induces tissue-specific epigenetic and transcriptional alterations to circadian clock genes in men. The fournal of 
Clinical Endocrinology \& Metabolism, 100(9), E1255-E1261. doi: 10.1210/jc.2015-2284

Convention for the Protection of Human Rights and Dignity of the Human Being with Regard to the Application of Biology and Medicine: Convention on Human Rights and Biomedicine, 1997.

Daud, A., Skoglund, E., \& Rydelius, P.-A. (2005). Children in families of torture victims: Transgenerational transmission of parents' traumatic experiences to their children. International fournal of Social Welfare, 14(1), 2332. doi: 10.1111/j.1468-2397.2005.00336.x

de Kloet, E. R., Joëls, M., \& Holsboer, F. (2005). Stress and the brain: From adaptation to disease. Nature Reviews Neuroscience, 6(6), 463-475. doi: $10.1038 / \mathrm{nrn} 1683$

Dekel, R., \& Goldblatt, H. (2008). Is there intergenerational transmission of trauma? The case of combat veterans' children. American fournal of Orthopsychiatry, 78(3), 281-289. doi: 10.1037/a0013955

Fillingim, R. B. (2005). Individual differences in pain responses. Current Rheumatology Reports, 7(5), 342-347. doi: 10.1007/s1 1926-005-0018-7

Gibney, E. R., \& Nolan, C. M. (2010). Epigenetics and gene expression. Heredity, 105(1), 4-13. doi: 10.1038/hdy.2010.54

Gilbertson, M. W., Shenton, M. E., Ciszewski, A., Kasai, K., Lasko, N. B., Orr, S. P., \& Pitman, R. K. (2002). Smaller hippocampal volume predicts pathologic vulnerability to psychological trauma. Nature Neuroscience, 5(11), 1242-1247. doi: $10.1038 / \mathrm{nn} 958$

Gola, H., Engler, H., Schauer, M., Adenauer, H., Riether, C., Kolassa, S., . . Kolassa, I.-T. (2012).Victims of rape show increased cortisol responses to trauma reminders: A study in individuals with war- and torture-related PTSD. Psychoneuroendocrinology, 37(2), 213-220. doi: 10.1016/j.psyneuen.2011.06.005

Good, A. (2004). 'Undoubtedly an expert'? Anthropologists in British asylum courts. The Fournal of the Royal Anthropological Institute, 10(1), 113-133. doi: 10.1111/j.1467-9655.2004.00182.x

Gorman, W. (2001). Refugee survivors of torture: Trauma and treatment. Professional Psychology: Research and Practice, 32(5), 443-451. doi: 10.1037/0735-7028.32.5.443

Greenberg, I. (2015). From surveillance to torture: The evolution of US interrogation practices during the War on Terror. Security fournal, 28(2), 165-183. doi: 10.1057/sj.2015.7

Heinzelmann, M., \& Gill, J. (2013). Epigenetic mechanisms shape the biological response to trauma and risk for PTSD: A critical review. Nursing Research and Practice, 2013, 417010. doi: $10.1155 / 2013 / 417010$

Horsthemke, B. (2018). A critical view on transgenerational epigenetic inheritance in humans. Nature Communications, 9(1), 2973. doi: 10.1038/s41467-018-05445-5

Houtepen, L. C., Hardy, R., Maddock, J., Kuh, D., Anderson, E. L., Relton, C. L., . . Howe, L. D. (2018). Childhood adversity and DNA methylation in two population-based cohorts. Translational Psychiatry, 8(1), 266. doi: 10.1038/ s41398-018-0307-3

Jaenisch, R., \& Bird, A. (2003). Epigenetic regulation of gene expression: How the genome integrates intrinsic and environmental signals. Nature Genetics, 33(Suppl), 245-254. doi: 10.1038/ ng1089

Jaranson, J. M., Butcher, J., Halcon, L., Johnson, D. R., Robertson, C., Savik, K., . . Westermeyer, J. (2004). Somali and Oromo refugees: Correlates of torture and trauma history. American fournal of Public Health, 94(4), 591-598. doi: 10.2105/ ajph.94.4.591

Kang, H.-J., Kim, J.-M., Stewart, R., Kim, S.-Y., Bae, K.-Y., Kim, S.-W., . . Yoon, J.-S. (2013). Association of SLC6A4 methylation with early adversity, characteristics and outcomes in depression. Progress in Neuro-Psychopharmacology and Biological Psychiatry, 44, 23-28. doi: 10.1016/j.pnpbp.2013.01.006

Kang, J. I., Kim, T.Y., Choi, J. H., So, H. S., \& Kim, S. J. (2019). Allele-specific DNA methylation level of FKBP5 is associated with post-traumatic stress disorder. Psychoneuroendocrinology, 103, 1-7. doi: 10.1016/j.psyneuen.2018.12.226

Karl, A., Schaefer, M., Malta, L. S., Dörfel, D., Rohleder, N., \& Werner, A. (2006). A metaanalysis of structural brain abnormalities in PTSD. Neuroscience E Biobehavioral Reviews, 30(7), 1004-1031. doi: 10.1016/j. neubiorev.2006.03.004

Kelly, T. (2011). What we talk about when we talk about torture. Humanity: An International Fournal of Human Rights, Humanitarianism, and Development, 2(2), 327-343. https://muse.jhu.edu/ journal/499

Kim, T.Y., Kim, S. J., Chung, H. G., Choi, J. H., Kim, S. H., \& Kang, J. I. (2017). Epigenetic alterations of the $B D N F$ gene in combat-related post-traumatic stress disorder. Acta Psychiatrica Scandinavica, 135(2), 170-179. doi: 10.1111/ acps. 12675

Kirschner, R. H., \& Hannibal, K. E. (1994). The application of the forensic sciences to human 
rights investigations. Medicine and Law, 13, 451460.

Kolassa, I.-T., \& Elbert, T. (2007). Structural and functional neuroplasticity in relation to traumatic stress. Current Directions in Psychological Science, 16(6), 321-325. doi: 10.1111/j.14678721.2007.00529.x

Kuroda, A., Rauch, T. A., Todorov, I., Ku, H. T., Al-Abdullah, I. H., Kandeel, F., . . F Ferreri, K. (2009). Insulin gene expression is regulated by DNA methylation. PLoS ONE, 4(9), e6953. doi: 10.1371/journal.pone.0006953

Labonté, B., Suderman, M., Maussion, G., Navaro, L., Yerko, V., Mahar, I., . . Turecki, G. (2012). Genome-wide epigenetic regulation by early-life trauma. Archives of General Psychiatry, 69(7), 722731. doi: 10.1001 /archgenpsychiatry.2011.2287

Maculan, E. (2015). Judicial definition of torture as a paradigm of cross-fertilisation: Combining harmonisation and expansion. Nordic fournal of International Law, 84(3), 456-481. doi: 10.1163/15718107-08403005

Martín-Blanco, A., Ferrer, M., Soler, J., Salazar, J., Vega, D., Andión, O., . . Pascual, J. C. (2014). Association between methylation of the glucocorticoid receptor gene, childhood maltreatment, and clinical severity in borderline personality disorder. Fournal of Psychiatric Research, 57, 34-40. doi: 10.1016/j. jpsychires.2014.06.011

Marzi, S. J., Sugden, K., Arseneault, L., Belsky, D. W., Burrage, J., Corcoran, D. L., . . Caspi, A. (2018). Analysis of DNA methylation in young people: Limited evidence for an association between victimization stress and epigenetic variation in blood. American fournal of Psychiatry, 175(6), 517-529. doi: 10.1176/appi. ajp.2017.17060693

Masmas, T. N., Møller, E., Buhmann, C., Bunch, V., Jensen, J. H., Hansen, T. N., . . . Ekstrøm, M. (2008). Asylum seekers in Denmark: A study of health status and grade of traumatization of newly arrived asylum seekers. Torture fournal, 18(2), 77-86.

McColl, H., Bhui, K., \& Jones, E. (2012). The role of doctors in investigation, prevention and treatment of torture. Fournal of the Royal Society of Medicine, 105(11), 464-471. doi: 10.1258/ jrsm.2012.120100

McGowan, P. O., Sasaki, A., D'Alessio, A. C., Dymov, S., Labonté, B., Szyf, M., . . . Meaney, M. J. (2009). Epigenetic regulation of the glucocorticoid receptor in human brain associates with childhood abuse. Nature Neuroscience, 12(3), 342-348. doi: 10.1038/nn.2270
Nash, M., Galatzer-Levy, I., Krystal, J. H., Duman, R., \& Neumeister, A. (2014). Neurocircuitry and neuroplasticity in PTSD. In M. J. Friedman, T. M. Keane \& P. A. Resick (Eds.), Handbook of PTSD: Science and practice (2nd ed.). New York: The Guilford Press.

Nautiyal, K. M., \& Hen, R. (2017). Serotonin receptors in depression: From A to B. F1000Research, 6, 123. doi: 10.12688/ f1000research.9736.1

Nickerson, A., Schick, M., Schnyder, U., Bryant, R. A., \& Morina, N. (2017). Comorbidity of posttraumatic stress disorder and depression in tortured, treatment-seeking refugees. Fournal of Traumatic Stress, 30(4), 409-415. doi: 10.1002/ jts. 22205

Nishi, M., \& Nanjo, K. (2011). Insulin gene mutations and diabetes. Fournal of Diabetes Investigation, 2(2), 92-100. doi: 10.1111/j.20401124.2011.00100.x

OHCHR (2004). Istanbul Protocol: Manual on the Effective Investigation and Documentation of Torture and Other Cruel, Inhuman or Degrading Treatment or Punishment. New York: United Nations (Istanbul Protocol).

Penney, J., \& Tsai, L.-H. (2014). Histone deacetylases in memory and cognition. Science Signaling, 7(355), re12. doi: 10.1126/scisignal.aaa0069

Pérez-Sales, P. (2017). Psychological torture: Definition, evaluation and measurement. Abingdon: Routledge.

Pérez-Sales, P., Navarro-Lashayas, M. A., Plaza, A., Morentin, B., \& Barrios Salina, O. (2016). Incommunicado detention and torture in Spain, part III: 'Five days is enough': The concept of torturing environments. Torture fournal, 26(3), 21-33.

Pérez-Sales, P., Witcombe, N., \& Otero Oyague, D. (2017). Rehabilitation of torture survivors and prevention of torture: Priorities for research through a modified Delphi Study. Torture fournal, 27(3), 3-37. doi: 10.7146/torture.v27i3.103976

Perroud, N., Paoloni-Giacobino, A., Prada, P., Olié, E., Salzmann, A., Nicastro, R., . . . Malafosse, A (2011). Increased methylation of glucocorticoid receptor gene (NR3C1) in adults with a history of childhood maltreatment: A link with the severity and type of trauma. Translational Psychiatry, 1, e59. doi: 10.1038/tp.2011.60

Petersen, H. D., \& Morentin, B. (2019). Assessing the level of credibility of allegations of physical torture. Forensic Science International, 301, 263270. doi: 10.1016/j.forsciint.2019.05.043

Plant, D. T., Pawlby, S., Pariante, C. M., \& Jones, F. W. (2018). When one childhood meets another - maternal childhood trauma and offspring child 
psychopathology: A systematic review. Clinical Child Psychology and Psychiatry, 23(3), 483-500. doi: 10.1177/1359104517742186

Ramo-Fernández, L., Boeck, C., Koenig, A. M., Schury, K., Binder, E. B., Gündel, H., . . . Kolassa, I.-T. (2019). The effects of childhood maltreatment on epigenetic regulation of stressresponse associated genes: An intergenerational approach. Scientific Reports, 9(1), 983. doi: 10.1038/s41598-018-36689-2

Rasmussen, A., Crager, M., Keatley, E., Keller, A. S., \& Rosenfeld, B. (2011). Screening for torture: A narrative checklist comparing legal definitions in a torture treatment clinic. Fournal of Psychology, 219(3), 143-149. doi: 10.1027/2151-2604/ a000061

Rejali, D. (2007). Torture and democracy. Princeton: Princeton University Press.

Reyes, H. (2007). The worst scars are in the mind: Psychological torture. International Review of the Red Cross, 89(867), 591-617.

Röder, P. V., Wu, B., Liu, Y., \& Han, W. (2016). Pancreatic regulation of glucose homeostasis. Experimental \& Molecular Medicine, 48(3), e219. doi: 10.1038/emm.2016.6

Rodley, N., \& Pollard, M. (2009). The treatment of prisoners under international law (3rd ed.). Oxford: Oxford University Press.

Rome Statute of the International Criminal Court, 1998, art. 7.2(e).

Ron, J. (1997). Varying methods of state violence. International Organization, 51(2), 275-300. doi: 10.1162/002081897550366

Roth, B. (2013). How do you know when it is torture? Medicine and Law, 32, 327-346. https:// wafml.memberlodge.org/page-1150634

Rusiecki, J. A., Chen, L., Srikantan, V., Zhang, L., Yan, L., Polin, M. L., \& Baccarelli, A. (2012). DNA methylation in repetitive elements and post-traumatic stress disorder: a casecontrol study of US military service members. Epigenomics, 4(1), 29-40. doi: 10.2217/epi.11.116

Sangalang, C. C., \& Vang, C. (2017). Intergenerational trauma in refugee families: A systematic review. Fournal of Immigrant and Minority Health, 19(3), 745-754. doi: 10.1007/ s10903-016-0499-7

Sheerin, C. M., Lind, M. J., Bountress, K. E., Nugent, N. R., \& Amstadter, A. B. (2017). The genetics and epigenetics of PTSD: Overview, recent advances, and future directions. Current Opinion in Psychology, 14, 5-11. doi: 10.1016/j. copsyc.2016.09.003

Skvortsova, K., Iovino, N., \& Bogdanović, O. (2018). Functions and mechanisms of epigenetic inheritance in animals. Nature Reviews Molecular Cell Biology, 19(12), 774-790. doi: 10.1038/ s41580-018-0074-2

Steel, Z., Chey, T., Silove, D., Marnane, C., Bryant, R. A., \& van Ommeren, M. (2009). Association of torture and other potentially traumatic events with mental health outcomes among populations exposed to mass conflict and displacement: A systematic review and meta-analysis. $\mathcal{F A M A}$, 302(5), 537-549. doi: 10.1001/jama.2009.1132

Steudte-Schmiedgen, S., Kirschbaum, C., Alexander, N., \& Stalder, T. (2016). An integrative model linking traumatization, cortisol dysregulation and posttraumatic stress disorder: Insight from recent hair cortisol findings. Neuroscience $\mathcal{E}$ Biobehavioral Reviews, 69, 124-135. doi: 10.1016/j.neubiorev.2016.07.015

Tiffon, C. (2018). The impact of nutrition and environmental epigenetics on human health and disease. International fournal of Molecular Sciences, 19(11), 3425. doi: 10.3390/ijms 19113425

Tsankova, N. M., Berton, O., Renthal, W., Kumar, A., Neve, R. L., \& Nestler, E. J. (2006). Sustained hippocampal chromatin regulation in a mouse model of depression and antidepressant action. Nature Neuroscience, 9(4), 519-525. doi: 10.1038/ nn 1659

Turner, S., \& Gorst-Unsworth, C. (1990). Psychological sequelae of torture: A descriptive model. The British fournal of Psychiatry, 157(4), 475-480. doi: 10.1192/bjp.157.4.475

Uchida, S., Yamagata, H., Seki, T., \& Watanabe, Y. (2018). Epigenetic mechanisms of major depression: Targeting neuronal plasticity. Psychiatry and Clinical Neurosciences, 72(4), 212227. doi: $10.1111 / \mathrm{pcn} .12621$

UN Convention against Torture and Other Cruel, Inhuman or Degrading Treatment or Punishment, 1984, art. 1.1

Van Ommeren, M., de Jong, J. T. V. M., Sharma, B., Komproe, I., Thapa, S. B., \& Cardeña, E. (2001). Psychiatric disorders among tortured Bhutanese refugees in Nepal. Archives of General Psychiatry, 58(5), 475-482. doi: 10.1001/archpsyc.58.5.475

Vidaki, A., \& Kayser, M. (2018). Recent progress, methods and perspectives in forensic epigenetics. Forensic Science International. Genetics, 37, 180195. doi: 10.1016/j.fsigen.2018.08.008

Vijayendran, M., Beach, S. R. H., Plume, J. M., Brody, G. H., \& Philibert, R. A. (2012). Effects of genotype and child abuse on DNA methylation and gene expression at the serotonin transporter. Frontiers in Psychiatry, 3, 55. doi: 10.3389/fpsyt.2012.00055

Vinkers, C. H., Kalafateli, A. L., Rutten, B. P. F., Kas, 
M. J., Kaminsky, Z., Turner, J. D., \& Boks, M. P. M. (2015). Traumatic stress and human DNA methylation: A critical review. Epigenomics, 7(4), 593-608. doi: 10.2217/epi.15.11

Wankerl, M., Miller, R., Kirschbaum, C., Hennig, J., Stalder, T., \& Alexander, N. (2014). Effects of genetic and early environmental risk factors for depression on serotonin transporter expression and methylation profiles. Translational Psychiatry, 4(6), e402. doi: 10.1038/tp.2014.37

Weaver, I. C. G., Cervoni, N., Champagne, F. A., D'Alessio, A. C., Sharma, S., Seckl, J. R., . . . Meaney, M. J. (2004). Epigenetic programming by maternal behavior. Nature Neuroscience, 7(8), 847-854. doi: 10.1038/nn 1276

Weisleder, P., \& Rublee, C. (2018). The neuropsychological consequences of armed conflicts and torture. Current Neurology and Neuroscience Reports, 18(3), 9. doi: 10.1007/ s11910-018-0818-6

Williams, A. C. d. C., \& Amris, K. (2017). Treatment of persistent pain from torture: Review and commentary. Medicine, Conflict and Survival, 33(1), 60-81. doi: $10.1080 / 13623699.2016 .1242050$

Williams, R., \& Wienroth, M. (2017). Social and ethical aspects of forensic genetics: A critical review. Forensic Science Review, 29(2), 146-169. http://forensicsciencereview.com

WMA. (2013). World Medical Association Declaration of Helsinki: Ethical Principles for Medical Research Involving Human Subjects. $\mathcal{F A M A}, 310(20), 2191$. doi: $10.1001 /$ jama.2013.281053

Yehuda, R., Daskalakis, N. P., Lehrner, A., Desarnaud, F., Bader, H. N., Makotkine, I., . . Meaney, M. J. (2014). Influences of maternal and paternal PTSD on epigenetic regulation of the glucocorticoid receptor gene in Holocaust survivor offspring. American fournal of Psychiatry, 171(8), 872-880. doi: 10.1176/appi. ajp.2014.13121571

Yehuda, R., Flory, J. D., Bierer, L. M., Henn-Haase, C., Lehrner, A., Desarnaud, F., . . Meaney, M. J. (2015). Lower methylation of glucocorticoid receptor gene promoter $1_{\mathrm{F}}$ in peripheral blood of veterans with posttraumatic stress disorder. Biological Psychiatry, 77(4), 356-364. doi: 10.1016/j.biopsych.2014.02.006

Yehuda, R., Daskalakis, N. P., Bierer, L. M., Bader, H. N., Klengel, T., Holsboer, F., \& Binder, E. B. (2016). Holocaust exposure induced intergenerational effects on FKBP5 methylation. Biological Psychiatry, 80(5), 372-380. doi: 10.1016/j.biopsych.2015.08.005
Zannas, A. S., Provençal, N., \& Binder, E. B. (2015) Epigenetics of posttraumatic stress disorder: Current evidence, challenges, and future directions. Biological Psychiatry, 78(5), 327-335. doi: 10.1016/j.biopsych.2015.04.003

Zhang, L., Benedek, D. M., Fullerton, C. S., Forsten, R. D., Naifeh, J. A., Li, X. X., . . Ursano, R. J. (2014). PTSD risk is associated with BDNF Val66Met and BDNF overexpression. Molecular Psychiatry, 19(1), 8-10. doi: 10.1038/ mp.2012.180 